ISLAMIC BANKING: Jurnal Pemikiran dan Pengembangan Perbankan Syariah, Volume 7 Nomor 2 Edisi Februari 2022

\title{
DETERMINANTS OF CAPITAL STRUCTURE POLICY AT INDONESIAN SHARIA BANK DEMANG PALEMBANG BRANCH
}

\author{
Fadilla \\ Sekolah Tinggi Ekonomi dan Bisnis Syariah (STEBIS) Indo Global Mandiri \\ Email: dilla@ stebisigm.ac.id \\ Lidya Pissatia Asih \\ Sekolah Tinggi Ekonomi dan Bisnis Syariah (STEBIS) Indo Global Mandiri \\ Email: lidya@student.stebisigm.ac.id
}

\begin{abstract}
The perpose of this study to aim influece of ROA (return on Asset), ROE (return on equity) dan DER (Debt to equity ratio) to DR (Debt ratio) in Sharia Islamic Banking Demang Lebar Daun Palembang. Analysis of data using multiple regression analysis tools. The result of this study ROA, ROE and DER simultaneosly effect the Debt ratio, but there are no partialy effect ROA dan ROE to Debt ratio, and DER have partialy effect to debt ratio. This study focus on ROA, ROE, DER and Debt ratio. This study usefeul further reseach to discuss about capital structure.
\end{abstract}

Keyword : ROA (return on Asset), ROE (return on equity), DER (Debt to equity ratio) to DR (Debt ratio)

\begin{abstract}
Abstrak
Tujuan penelitian ini untuk mengetahui pengaruh ROA (return on Asset), ROE (return on equity) dan DER (Debt to equity ratio) terhadap DR (Debt ratio) pada Bank Syariah Indonesia Cabang Demang. Analisis data yang digunakan dalam penelitian ini adalah Analisi regresi linier berganda. ROA, ROE dan DER terbukti memiliki pengaruh secara bersama-sama terhadap Debt ratio, sedangkan secara parsial ROA dan ROE tidak berpengaruh terhadap Debt ratio namun DER berpengaruh terhadap Debt ratio. Penelitian ini berfokus kepada ROA. ROE, DER dan Debt ratio. Penelitian ini berguna bagi peneliti yang akan melakukan penelitian tentang struktur modal.
\end{abstract}

Kata Kunci : ROA (return on Asset), ROE (return on equity), DER (Debt to equity ratio) to DR (Debt ratio) 
214 Fadilla \& Lidya Pissatia Asih, Determinant of Capital Structure Policy of Indonesian Sharia Bank..

\section{Introduction}

Although the development of Islamic banking has shown its fangs, some economic observers have seen the opposite. Islamic Economics researcher from SEBI School of Islamic Economics Aziz Setiawan said that the market share of Islamic banks was still stagnant at 5.3-5.5\%. Therefore, Aziz considers that the government's plan to merge four (4) Islamic banks into one (1) Mega Bank is appropriate. The two sharia banks that will be merged are Bank Syariah Mandiri (BSM) with Bank Rakyat Indonesia Syariah (BRIS), while Bank Negara Indonesia Syariah (BNI Syariah) is merged with the Sharia Business Unit of the State Savings Bank (UUS BTN).

Aziz considers that the merger of the 4 (four) Islamic State-Owned Banks will boost the assets of Islamic Banks in Indonesia. This was revealed in an interview with the newspaper Republika. "From the scale of financing with a merger, of course, the capital capacity will increase and provide leverage to collect larger deposits so that the scale of financing is also larger," said Aziz to Republika. co.id, Monday (6/3). On February 1, 2021, Bank Syariah Mandiri (BSM), Bank Negara Indonesia Syariah BNIS, Bank Rakyat Indonesia Syariah (BRIS) merged into one large Islamic Bank, namely Bank Syariah Indonesia. The merger of these three banks is expected to make Islamic banks' capital in Indonesia able to compete with existing conventional banks.

The problem of a company's capital structure is one of the problems for every company, including Islamic banking. Strong capital followed by good Human Resources (HR), as well as good cooperation provide smoothness and prosperity for a company to be able to continue to exist and as much as possible develop better from time to time.

Companies that lack working capital can result in reduced profits for the company itself. For the health of the company, working capital needs to always be available in sufficient and well managed as follows:

1. The financial manager devotes his time every day to the company's internal activities, especially the existence of working capital within the company so that the company can run smoothly.

2. Total current assets, generally greater than the total assets of other companies 
ISLAMIC BANKING: Jurnal Pemikiran dan Pengembangan Perbankan Syariah, Volume 7 Nomor 2 Edisi Februari 2022

3. Working capital management plays a role in small companies because small companies always need working capital to buy and sell goods with a high level of receivables turnover, even though in large companies working capital is also needed. (Musthafa, 2015)

Seeing the phenomenon of the merging of the three Islamic banks into one, namely Bank Syariah Indonesia (BSI) due to the reason that the capital structure is not optimal and seeing how important the capital structure is for each company, we intend to re-examine the factors that affect the capital structure. The object of research to be studied is the Indonesian Sharia Bank Demang Branch. Therefore, the title of this research is Determinants of Capital Structure Policy in Indonesian Islamic Banks (Case Study of BSI Demang Branch).

\section{Theoretical Basis}

\section{Understanding Capital Structure}

Every company needs funds to finance its company. Although the company does not have a profit, the company still needs capital to run the company's operational activities. Working capital is defined as the capital used to finance the daily operations of the company, especially those with a short period (Kasmir, 2014).

The use of working capital funds is generally used for the company's operational needs. Some of these include:
a. For payment of salaries, wages, and other operations
b. Purchase of raw materials or merchandise
c. To cover losses from the sale of securities
d. Establishment of funds for the purchase of fixed assets (land, buildings, vehicles, machinery, etc.)
e. Long term debt repayment
f. Purchase or recall of outstanding shares
g. Return or recall of outstanding shares
h. Taking money or goods for personal use
i. etc.(Kasmir, 2014) 
216 | Fadilla \& Lidya Pissatia Asih, Determinant of Capital Structure Policy of Indonesian Sharia Bank..

Every company will strive to achieve an optimal capital structure. The optimal capital structure is the capital structure that maximizes the company's share price. Several factors influence the capital structure, including: (1) sales stability, (2) asset structure, (3) operating leverage, (4) growth rate, (5) profitability, (6) tax, (7) control, ( 8) management attitude, (9) attitude of lenders and rating agencies, (10) market conditions, (11) internal conditions of the company, (12) financial flexibility .. (Brigham, Eugene F., and Houston, 2001). In this study, the factors that will be tested to see whether or not there is an influence on the capital structure are ROA (Return On Assets), ROE (Return on Equity), and Debt to Equity Ratio.

\section{Profitability Ratio}

Profitability is the ability of a company to generate profits. Profitability is used to describe the performance of management as seen from the company's profit. Many companies prefer to use the income received or use the company's internal finances as a source of financing the company's investment, but if the sources from within the company are not sufficient, then one way that can be used is to use debt or by issuing shares. as a last resort to meet financing. (Yudhiarti et al., 2016)

There are several components of this ratio, including profit margin, net profit margin, return on equity (ROE), return on assets (ROA). The formula for finding it includes:
a. Profit margin $=\frac{\text { laba kotor }}{\text { penjualan }}$
b. Net profit margin $\quad=\frac{\text { Eaning after tax }(E A T)}{\text { penjualan }}$
c. $\quad$ ROE $=\frac{E A T}{\text { Modal sendiri }}$
d. $\quad$ ROA $=\frac{E A T}{\text { total aktiva }}$

In this study, the profitability that will be used is ROA and ROE. The following is an example of a question and a discussion of how to find the ROA and ROE values.

a. It is known that the net sales of an Aneka Jaya company are Rp. 1800,000., while the company's HPP is Rp. 1,000,000., the interest expense is Rp. 50.000., 
ISLAMIC BANKING: Jurnal Pemikiran dan Pengembangan Perbankan Syariah, Volume 7 Nomor 2 Edisi Februari 2022

administration fee Rp. 30.000., tax on sales Rp. 20,000. The total net capital owned by the company is Rp. 5.000.000.

$$
\begin{aligned}
\mathrm{ROE} & =\frac{E A T}{\text { Modal sendiri }} \\
& =\frac{7.00 .000 .}{5.000 .000 .} \\
& =0,14(14 \%)
\end{aligned}
$$

This means that the company's capital has a profit of $14 \%$.

b. It is known that the net sales of an Aneka Jaya company are Rp. 1800,000., while the company's HPP is Rp. 1,000,000., the interest expense is Rp. 50.000., administration fee Rp. 30.000., tax on sales Rp. 20,000. The total assets owned by the company are Rp. 15.000.000.

$$
\begin{array}{ll}
\text { ROA } & =\frac{E A T}{\text { total aktiva }} \\
\text { ROA } & =\frac{7.00 .000 .}{15.000 .000 .} \\
& =0,046(4,6 \%)
\end{array}
$$

This means that of the total assets of the company, it can only own $4.6 \%$.

\section{Debt to Equity Ratio}

Debt to equity ratio is the debt ratio used to measure the ratio between total debt and equity (own capital). The formula used to calculate it is:

Debt to equity ratio $=\frac{\text { Total hutang }}{\text { total modal }}($ Musthafa, 2015)

\section{Debt Ratio}

Debt ratio is a debt ratio used to measure the ratio between total debt and total assets. The formula used to calculate it is

$$
\text { Debt ratio }=\frac{\text { Total hutang }}{\text { total aktiva }}(\text { Musthafa, 2015) }
$$

\section{Capital Structure Theory}

The theories concerning the capital structure are:

1). Traditional Approach Theory 
218 Fadilla \& Lidya Pissatia Asih, Determinant of Capital Structure Policy of Indonesian Sharia Bank..

The traditional approach suggests that there is an optimal capital structure and a company that can increase the total value of the company and uses a certain amount of debt (financial leverage). By using a growing debt. Initially, the company can reduce the cost of capital and increase the value the company.

2). The theory of the Modigliani-Miller approach

Modigliani-Miller stated that the capital structure does not affect the company's cost of capital and also does not affect the value of the company. According to MM. the total value of the company is not affected by the capital structure. rather it is influenced by the investment made by the company and the company's ability to generate profits.

\section{3). Trade-off theory}

This theory says that firms balance the benefits of financing and debt with higher interest rates and bankruptcy costs. (Bringham and Houston 2001:34). The company's decision to use debt is based on a balance between tax savings and the cost of financial distress. To evaluate funding alternatives based on consideration of tax savings, financial distress costs, and agency. However, there is one consideration that is overlooked, namely the right time.

\section{4). Pecking Order Theory}

This theory states that managers prefer internal funding over external funding. If the company determines funding from outside. managers tend to choose the safest securities. Like debt. Companies can accumulate cash to avoid funding from outside the company.

\section{5). Signaling Theory}

This theory states that companies that can generate profits tend to increase their debt because the additional interest paid will be balanced with profit before taxes. (Suhendra, 2012)

To measure the capital structure owned by the company can use the leverage ratio. Leverage ratio according to Sawyer (2005:13) is this ratio shows the company's ability to meet all its financial obligations if the company at that time was liquidated. The leverage ratios that can be used are: 
ISLAMIC BANKING: Jurnal Pemikiran dan Pengembangan Perbankan Syariah, Volume 7 Nomor 2 Edisi Februari 2022

a) Debt ratio or Debt Ratio (debt to total Aet Ratio)

This ratio shows the proposition between the liabilities owned and the total wealth owned. The higher the percentage yield, the greater the financial risk for creditors and holding shares.

b) Debt To Equity Ratio Or DER (Debt To Equity Ratio)

This ratio describes the ratio of debt and equity in the company's funding and shows the ability of the company's capital to meet all obligations.

c) Ratio of Debt to Interest Expense or TIE (Times Interest Earned)

This ratio is also called the closing ratio because it measures the ability to meet annual interest obligations with operating profit (EBIT). the extent to which operating profit may decrease without causing failure to fulfill the obligation to pay interest on the loan.

d) Fixed Load Coverage Ratio (Fix Change Coverage)

This ratio is similar to the TIE ratio, but this ratio is more complete because in this ratio the company's liabilities are taken into account if the company does leasing (leasepurchase) assets and allows long-term debt based on a lease-purchase contract. (Suhendra, 2012)

\section{Previous Research}

Nita and Anam conducted a study entitled Analysis of Factors Affecting the Capital Structure of Mining Sector Companies. The results of the research show that profitability, liquidity, asset structure, growth rate, and firm size have a simultaneous influence on capital structure. While profitability and firm size have a partial effect, the variables of liquidity, asset structure, and growth rate do not significantly affect the capital structure. (Nita \& Hairul, 2017)

Rohadatul and Imron conducted a study entitled Factors Affecting the Growth of Islamic Bank Assets in Indonesia in 2006-2015. The results of this study prove that the external has a significant negative effect on the internal factors of Islamic banks in Indonesia of 0.873; external factors do not have a significant influence on the growth of Islamic bank assets in Indonesia; internal factors do not have a significant influence on 
the growth of Islamic bank assets in Indonesia; and the factors that most influence the growth of Islamic bank assets are internal factors, external factors through internal factors, and direct external factors. ("Rohadatul," 2015)

Marek conducted a study in 2015 with the title Analysis of Factors influencing the capital structure of manufacturing companies listed on the Indonesia Stock Exchange (on Food and Beverage Companies for the Period 2007-2010). The results of the research show that company size, business risk, has no significant effect on capital structure, but profitability has a significant effect on capital structure. (Marentek et al., 2015)

Yudhiarti (et al) conducted a study entitled Analysis of Factors Affecting Capital Structure in Manufacturing Companies Listed on the Indonesia Stock Exchange in 2010-2014). The results show that profitability, sales growth, asset structure, cash holding, liquidity, and company size influence the capital structure (DER). (Yudhiarti et al., 2016)

Kesuma conducted a study entitled Analysis of Factors Affecting Capital Structure and Its Effect on Share Prices of Real Estate Companies that Go Public on the Indonesia Stock Exchange. The results of his research show that sales growth has a negative or opposite effect on the capital structure. Profitability has the opposite effect on the capital structure and the magnitude of the direct influence on profitability with a capital structure of $4.1 \%$. Debt has a significant influence and is in line with the capital structure with a magnitude of the effect of $58.7 \%$. (Kesuma, n.d.)

Suhendra and Ruskina conducted a study entitled Capital Structure Analysis in Increasing Profits at PT. Bekasi Asri Pemula, Tbk Listed on the Indonesia Stock Exchange (2008-2012). The results show that the company's Debt Ratio in 2008-2012 has decreased. Debt to Equity The company's ratio fluctuated during the period 20082012. There was an increase in 2011 caused by the increase in the company's debt. The lower the Debt Equity Ratio. In Times Interest Earned the company experienced ups and downs caused by the amount of interest costs borne by the company. In 2008-2012 Return on Investment of PT Bekasi Asri Pemula, Tbk experienced fluctuations. The company experienced a decline in ROI occurred in the last two years, namely 2011- 
ISLAMIC BANKING: Jurnal Pemikiran dan Pengembangan Perbankan Syariah, Volume 7 Nomor 2 Edisi Februari 2022

2012. This decrease occurred due to an increase in the number of assets but was followed by profit. (Suhendra, 2012)

Neno conducted a study entitled Analysis of Factors Affecting the Capital Structure of Mining Companies Listed on the Indonesia Stock Exchange for the Period 2012-2016. The results of this study indicate that the results of this study indicate that profitability has a negative and significant effect on Capital Structure, SIZE (firm size). has a positive and significant effect on the capital structure while the Asset Structure and GROWTH have no effect on the capital structure. (Neno, 2018)

Hidayat conducted a study entitled Analysis of the factors that affect the capital structure of manufacturing companies listed on the Indonesia Stock Exchange for the period 2007-2011. The results of this study indicate that sales growth and debt service ratio have an effect on capital structure, while non-debt tax shield has no effect on capital structure. (Hidayat, 2013)

Setiawati conducted research entitled the factors that affect the capital structure (Survey on Sanitaer Companies in Jambi City). The results of this study indicate that the financial manager of the sanitary business in Jambi city in determining the right amount of debt to fund the business is related to profitability, manager ownership, sustainability, cash flow, opportunity (business opportunities), signaling for customers and business motivation factors. (Setiawati, 2011)

Fadilla conducted a study entitled Determinants of Capital Structure Policy and Its Effect on Stock Prices (In Companies Listed in the Jakarta Islamic Index). The results of this study indicate that there is a significant effect between retained earnings and ROA on stock prices directly. Meanwhile, the asset structure, current ratio, and PER (price earning ratio) have no direct effect on stock prices. Retained earnings, ROA, asset structure, current ratio, and PER (price earning ratio) do not affect stock prices through DER intermediaries (debt to equity ratio). (Fadilla, 2015)

Yushinta and Erni conducted a study entitled Analysis of factors that affect capital structure (Empirical Study of Manufacturing Companies on the Indonesia Stock Exchange). The results of this study indicate that sales growth and firm size have a positive and significant effect on capital structure, while profitability has a negative and 
222 Fadilla \& Lidya Pissatia Asih, Determinant of Capital Structure Policy of Indonesian Sharia Bank..

significant effect on capital structure. So the company should consider these factors so that the capital structure can be used effectively and efficiently to produce good performance for the company. (Yusintha \& Suryandari, 2010). Firnanti conducted a study entitled Factors that affect the capital structure of Manufacturing Companies on the Indonesia Stock Exchange. The results of this study indicate that company size and business risk have a significant influence on the capital structure of manufacturing companies on the Indonesia Stock Exchange. (Firnanti, 2011)

Murhadi conducted a study entitled Determinants of Capital Structure: Studies in Southeast Asia in 2011. The results of his research show that the factors that determine debt policy in companies that are members of the mining sector are profitability, company size, real assets, and growth rates, while savings taxes that are not sourced from debt have no significant effect. This study also finds that there is no significant difference in practice between the use of debt in the six ASEAN countries. This research generally supports the pecking order theory, where companies tend to use internal funding to finance their investments (Murhadi, 1984)

Nuswandi in 2013 conducted a study entitled Determinants of Capital Structure in the Perspective of Pecking Order Theory and Agency Theory. The results show that firm size has a significant positive effect on the capital structure variable. Therefore, the hypothesis is rejected because the size of the company's direction is the opposite hypothesis. Variable growth opportunities and managerial ownership have a significant negative effect on capital structure. (Cahyo \& Amelia, n.d.)

Indriastuti and Suhendi conducted a study entitled Financial Risk Analysis For Increasing Financial Performance of Sharia Banks in Indonesia. The test results show that financial risk affects the performance of Islamic banks in Indonesia. (Indriastuti et al., 2021)

\section{Framework for Thinking and Formulation of Hypotheses}

This study aims to examine the effect of ROA (Return On Assets), ROE (Return on Equity), and Debt to Equity Ratio (DER) on the debt ratio. For more details, it will be described in the chart below 
ISLAMIC BANKING: Jurnal Pemikiran dan Pengembangan Perbankan Syariah, Volume 7 Nomor 2 Edisi Februari 2022

Picture 2.1.

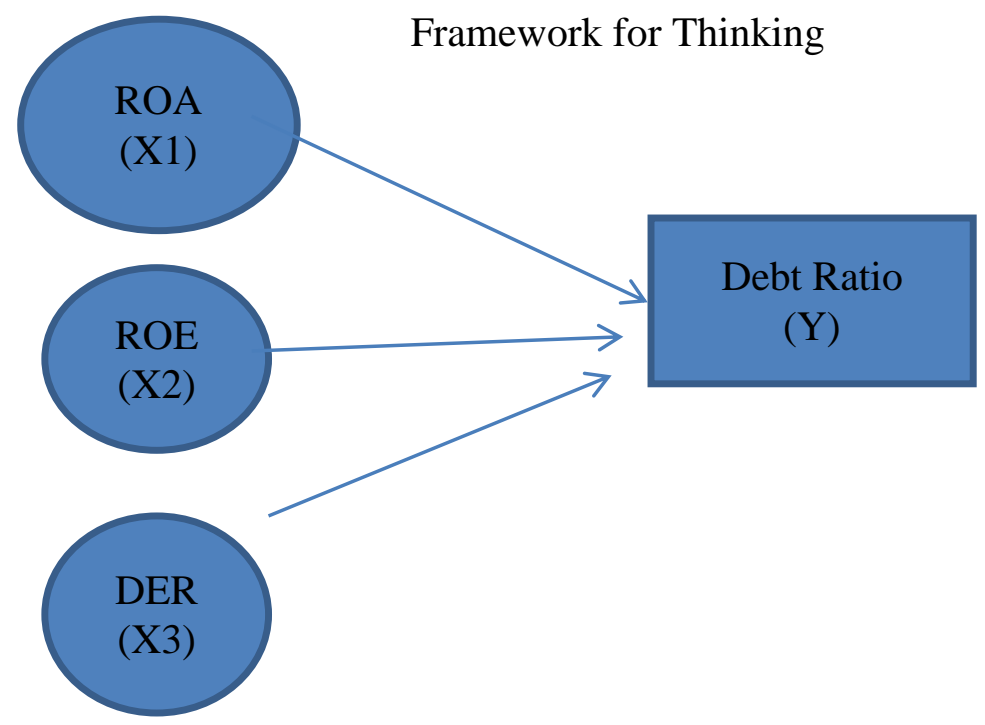

In the Pecking Order Theory which states that companies tend to use internal funds first and then external funds. Return on Assets is the return or profit obtained from the total assets of the company. This means that if the company has profits from total assets, the company will use these profits to finance the company rather than in debt. Therefore, the first hypothesis in this study is:

\section{H1. : ROA Affects Debt Ratio}

In the company's Pecking order theory, there is a tendency for companies to use internal funds first and then external funds. Return on Equity is a return or profit obtained from the total assets of the company. This means that if the company has profits from total assets, the company will use these profits to finance the company rather than in debt. Therefore, the first hypothesis in this study is:

\section{H2 : ROE Affects Debt Ratio}

On the trade off theory, this theory says that companies balance the benefits of financing and debt with higher interest rates and bankruptcy costs. Based on this theory, the company is very likely to choose to fund its operational activities using debt, so the third hypothesis in this study is: 
224 Fadilla \& Lidya Pissatia Asih, Determinant of Capital Structure Policy of Indonesian Sharia Bank..

\section{H3 : DER Affects Debt Ratio}

Based on the theory of pecking order and trade off, it can be concluded that ROA, ROE and DER have an effect on DR (Debt ratio). So the fourth hypothesis in this study is:H4 : ROA, ROE, DER berpengaruh secara bersama-sama terhadap DR (Debt ratio).

\section{Research methods}

This research was conducted at the Indonesian Islamic Bank Branch Demang Lebar Daun Palembang. The Demang branch of Islamic Bank Indonesia is (ex) or was previously a Mandiri Syariah Bank. The data used in this research is quantitative. The method used in this research is quantitative research. Quantitative research is research in which the data in the research uses numbers or numerical data. The analysis used in this research is Multiple Linear Regression analysis. Regression analysis is a mathematical equation that defines the relationship between two variables. The dependent variable in this study is the Debt Ratio, while the independent variables are ROA (Return On Assets), ROE (Return on Equity) and Debt to Equity Ratio (DER) (Sunarto, 2017). The form of the regression equation is

$$
\begin{array}{ll}
\mathrm{Y}=\mathrm{a}+ & \mathrm{bX}_{1}+\mathrm{b}_{2} \mathrm{x}_{2}+\mathrm{b}_{3} \mathrm{x}_{3} \\
\text { Ket } & : \\
\mathrm{Y} & : \text { Debt ratio } \\
\mathrm{X} 1 & : \text { ROA (Return On Asset) } \\
\mathrm{X} 2 & : \text { ROE (Return on Equity) } \\
\mathrm{X} 3 & : \text { DER (Debt to Equity Ratio) } \\
\mathrm{Y} & : \text { Debt Ratio }
\end{array}
$$

\section{Test Results and Discussion}

\section{Descriptive Analysis Results}

Descriptive statistics is a part of statistics that studies how to collect data and present data so that it is easy to understand. Descriptive statistics only deals with describing or providing information about data or situations. The word descriptive 
ISLAMIC BANKING: Jurnal Pemikiran dan Pengembangan Perbankan Syariah, Volume 7 Nomor 2 Edisi Februari 2022

statistics function to explain the situation, symptom, or problem. Conclusions on descriptive statistics (if any) are only aimed at the existing data set. Descriptive analysis is data analysis using univariate statistics such as mean, median, mode, standard deviation, variance, etc. The purpose of this analysis is to determine the distribution of sample or population data. Descriptive analysis is a statistic used to analyze data by describing or describing the data that has been collected as it is without intending to make conclusions that apply to the public or generalizations. (Fadilla, 2017)

Tabel 4.1.

Hasil Analisis Deskriptif

Descriptive Statistics

\begin{tabular}{|l|r|r|r|r|r|}
\hline & $\mathrm{N}$ & Minimum & $\begin{array}{c}\text { Maximu } \\
\mathrm{m}\end{array}$ & \multicolumn{1}{c|}{ Mean } & $\begin{array}{c}\text { Std. } \\
\text { Deviation }\end{array}$ \\
\hline ROA & 55 & .0003671 & .0113594 & .004144096 & .0027406131 \\
ROE & 55 & .0000000 & .1380036 & .045157711 & .0322017984 \\
DER & 55 & 1.023000 & 1.168370 & 11.851621455 & 3.210984153 \\
& 55 & .9040940 & .9282400 & .917440200 & .0037775102 \\
DR & 55 & & & & \\
Valid N & & & & \\
(listwise) & & & & & \\
\hline
\end{tabular}

The data from the analysis above shows that the minimum ROA value of ROA is .0003671 , this means that the smallest value of ROA during the research period is $0.003 \%$, while the largest value is 0.0113594 which means $1.13 \%$ is the largest value for ROA. And the average value is 0.0 .00414 which means the average value for ROA is $0.04 \%$ while the standard deviation or deviation is 0.002740 .

The minimum ROE value of .0000000 means that during the research period there was never any ROE. Maximum value .1380036 means the largest ROE value during the research period is $13.8 \%$. The average ROE is .045157711 or $4.51 \%$, with a standard deviation of 0.0322 . The minimum DER value is 1.023 , which means the smallest debt guaranteed with a capital of 1 x. Maximum value 1.1683700E2, and Average 11.851621455. The minimum value of DR (Debt Ratio) is 0.904 , which means the smallest value for a debt ratio of $90.4 \%$, the maximum value of 0.928 indicates that the 
226 Fadilla \& Lidya Pissatia Asih, Determinant of Capital Structure Policy of Indonesian Sharia Bank...

largest value is $92.8 \%$ while the average is 0.9174 or $91.7 \%$. the average debt ratio is $91.7 \%$.

\section{Classic assumption test}

In contrast to simple linear regression analysis, the data used in multiple linear regression analysis must pass the classical assumption test. Classical assumption tests include multicollinearity, heteroscedasticity, autocorrelation, and linearity tests. However, in this study, there are only 3 tests that the authors will discuss, namely the multicollinearity test, heteroscedasticity, and linearity test. (Fadilla, 2017)

\section{1) Normality Test}

A normality test is conducted to test whether, in the regression model, there are confounding variables or residuals that are proven to be normally distributed or not. In this study, there are two ways to detect whether the residuals are normally distributed or not, namely graphical analysis and statistical tests. (Ghazali, 2017) In this study, the analysis used as graph analysis. If the Asymp value. Sig. (2-tailed >0.05) then the data is normally distributed whereas if the Asymp value. Sig. $(2$-tailed $<0.05)$ then the data is not normally distributed. The results of the graph analysis are as follows:

Tabel 4.2.

Hasil Uji Normalitas

One-Sample Kolmogorov-Smirnov Test

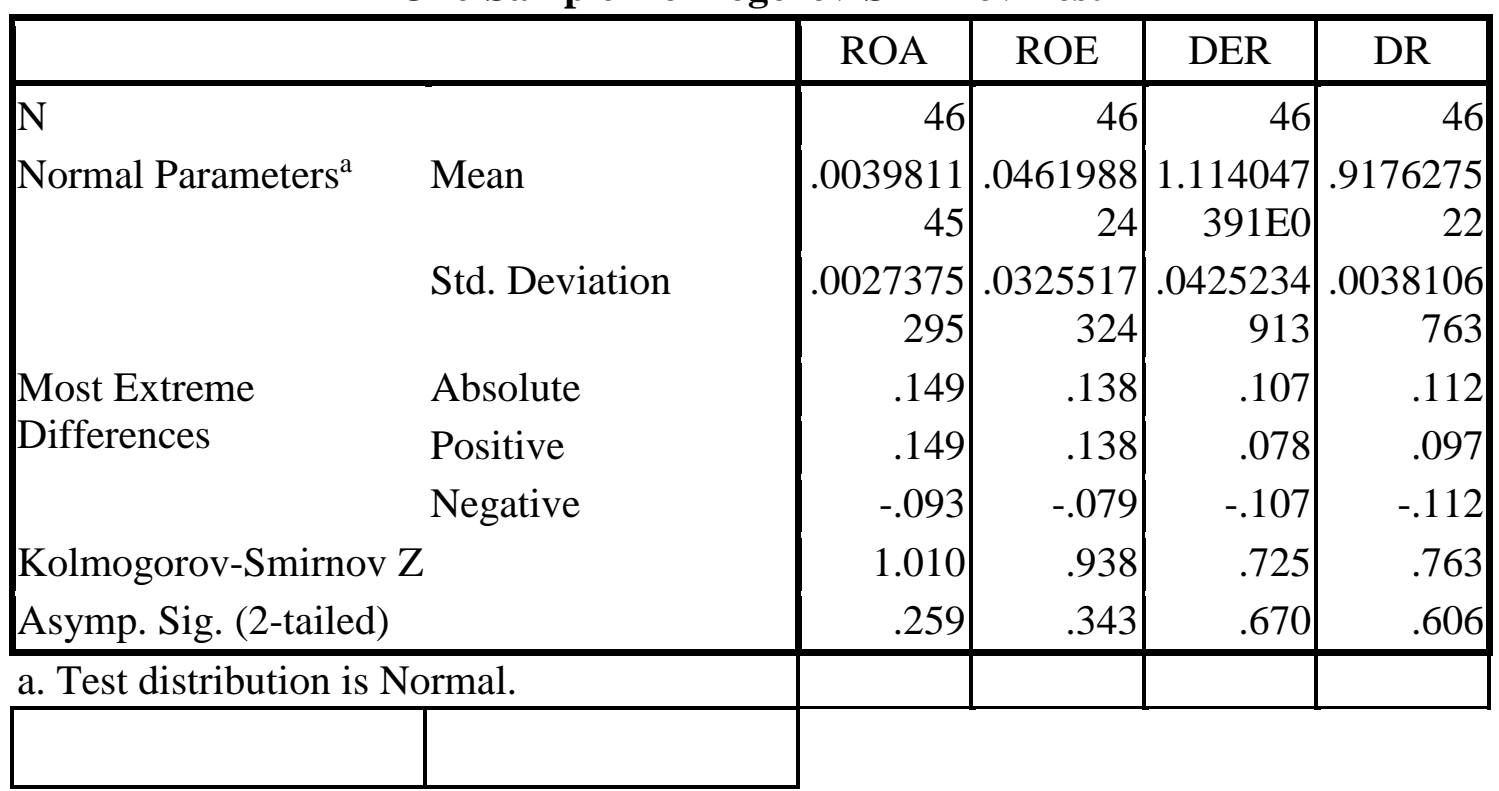


ISLAMIC BANKING: Jurnal Pemikiran dan Pengembangan Perbankan Syariah, Volume 7 Nomor 2 Edisi Februari 2022

In Table 4.2. above it can be seen that the value of Asymp. Sig. (2-tailed) 0.259 for the value of ROA (return on assets) this value is greater than 0.05 , this indicates that the ROA variable is normally distributed. Asymp Value. Sig. (2-tailed) 0.343 for the ROE (Return on Equity) value, this value is greater than 0.05, this indicates that the ROE variable is normally distributed. Asymp Value. Sig. (2-tailed) 0.670 for the value of DER (Debt Equity ratio) this value is greater than 0.05, this indicates that the DER variable is normally distributed. The Variable Debt ratio (DR) Asymp value. Sig. (2tailed) is 0.606 this value is also greater than 0.05 and indicates that it is normally distributed. So from the test results above prove that all variables in this study are normally distributed.

\section{2) Heteroscedasticity Test}

Heteroscedasticity test aims to test whether the regression model has variance inequality from one observation residual to another observation. If the points spread randomly and are spread both above and below the number 0 on the $\mathrm{Y}$ axis, it can be concluded that there is no heteroscedasticity in the regression model used. In the SPSS output graph above, it can be seen that the points spread randomly and are spread both above and below the number 0 on the $\mathrm{Y}$ axis, so it can be concluded that in this study there was no heteroscedasticity in the regression model used (Fadilla, 2017). The results of the heteroscedasticity test can be seen in the scatterplot image below:

Picture 4.1.

Scatterplot 


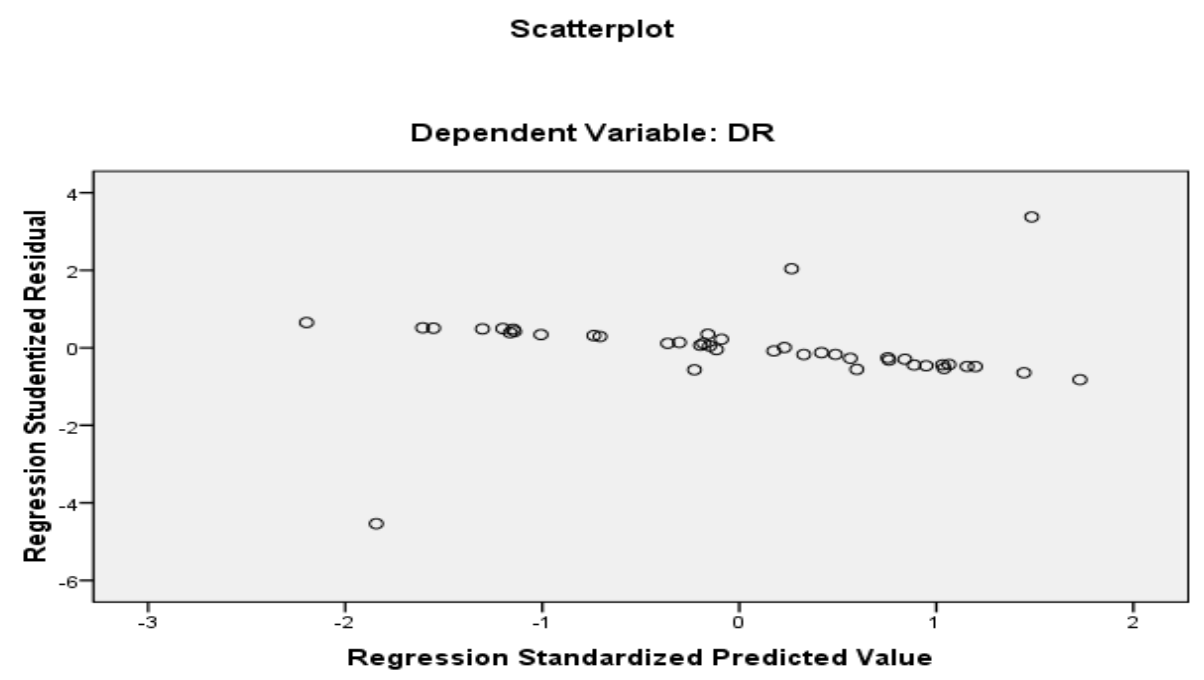

In Figure 4.1. above it can be seen that the points spread above 0 and below 0 in the image above. This means that the data used in this study has passed the heteroscedasticity test.

\section{3) Multicollinearity Test}

The Multilinearity test aims to test whether the regression model found a correlation between the independent variables (independent). A good regression model should not correlate with the independent variables. If the independent variables are correlated with each other, then these variables are not orthogonal. The nulticolinierity test can be seen from (1) the tolerance value and its opposite (2) the variance inflation factor (VIF). These two measures indicate which of each independent variable is explained by each of the other independent variables.). (Ghazali, 2007: 95) If the tolerance value is $>0.1$ and the VIF value is $<10$, the research conducted does not contain multicollinearity in the data. (Ghazali, 2017)

Tabel 4.3.

Uji Multikolinieritas

\begin{tabular}{|c|c|c|c|}
\hline Variabel & Tolerance & VIF & kesimpulan \\
\hline DER & .622 & 1.607 & $\begin{array}{c}\text { Lolos uji } \\
\text { multikoliniertitas }\end{array}$ \\
\hline ROA & .199 & 5.014 & $\begin{array}{c}\text { Lolos uji } \\
\text { multikoliniertitas }\end{array}$ \\
\hline ROE & .238 & 4.197 & $\begin{array}{c}\text { Lolos uji } \\
\text { multikoliniertitas }\end{array}$ \\
\hline
\end{tabular}




\section{4) Linearity Test}

Linearity test to see if the model specifications used are correct or not. Whether the function used in an empirical study should be in linear, quadratic or cubic form. In this study, the linearity test was carried out by looking at the value of Durbin Watson. If the value of DW > Table DW, this study passes the Durbin Watson test, which means that all data in this study are proven to be linearly usable. The values of the DW test are listed in the table below:

\section{Tabel 4.4.}

\section{Uji DW}

\begin{tabular}{|c|c|c|}
\hline DW Hitung & DW tabel & Kesimpulan \\
\hline 1,831 & 1,724 & Terbukti linier \\
\hline
\end{tabular}

In table 4.4. above, it is proven that the calculated DW value is 1.831 while the table DW is 1.724 which means that the calculated DW is > than the table DW. This shows that the data used in this research is linear data.

\section{Research Hypothesis Test}

1) Test the coefficient of determination

The coefficient of determination is used to test the goodness-fir of the regression model. The value of adjusted R2 is 0.768 , which means that the variable of the dependent variable which can be explained by the variability of the independent variable is $76.8 \%$. So the model is quite good. While the remaining $23.2 \%$ is explained by other variables that are not included in the regression model. (Ghazali, 2017) The results of the coefficient of determination test in this study are shown in table 4.4. below this

\section{Tabel 4.5}

\begin{tabular}{|c|c|}
\multicolumn{2}{|c|}{ Uji R $^{\mathbf{2}}$} \\
\hline Model & $\mathrm{R}^{2}$ \\
\hline Nilai & 0.825 \\
\hline
\end{tabular}


230 Fadilla \& Lidya Pissatia Asih, Determinant of Capital Structure Policy of Indonesian Sharia Bank

Table 45 above shows that the value of $\mathrm{R} 2$ is 0.825 , which means that the variables DER (Debt to equity ratio), ROA (Return on Assets), ROE (Return on Equity) can influence or explain DR (Debt Ratio) of 82.5\%. while the remaining 17.5\% (10082.5 ) is explained by other variables not included in this study. Based on the theory and the results of previous research, it can be seen that several other factors that can affect the capital structure include asset structure, company size, retained earnings, current ratio and many more.

2) F.test

Simultaneous effect test is used to determine whether the independent variable simultaneously or simultaneously affects the dependent variable. If the significance value is $<0.05$, then there is a simultaneous effect of the independent variable on the dependent variable and the research can be continued. Meanwhile, if the significance value is $>0.05$, then there is no simultaneous effect of the independent variable on the dependent variable, so the research cannot be continued. (Fadilla, 2017) The results of the $\mathrm{f}$ test are illustrated in the Anova table below

Tabel 4.6.

Tabel Anova

ANOVA ${ }^{b}$

\begin{tabular}{|ll|r|r|r|c|c|}
\hline \multicolumn{2}{|l|}{ Model } & \multicolumn{1}{|c|}{$\begin{array}{c}\text { Sum of } \\
\text { Squares }\end{array}$} & df & Mean Square & F & Sig. \\
\hline 1 & Regression & .000 & 3 & .000 & 59.541 & $.000^{\mathrm{a}}$ \\
& Residual & .000 & 38 & .000 & & \\
& Total & .001 & 41 & & & \\
\hline
\end{tabular}

a. Predictors: (Constant), Ln_ROE, DER, Ln_ROA

b. Dependent Variable: DR

The results of the significance test in the Anova table above are 0.000 with an $\mathrm{F}$ value of 59,941. This value is smaller than 0.05. This means that DER (Debt to equity ratio), ROA (Return on Assets), ROE (return on Equity) are proven to have a joint effect on DR (Debt Ratio). This means that the fourth hypothesis in this study is accepted. The results of this study support the results of research conducted by Setiawati (2011) and Suhendra and Ruskini and reject the results of research conducted by Hidayat (2013). 
ISLAMIC BANKING: Jurnal Pemikiran dan Pengembangan Perbankan Syariah, Volume 7 Nomor 2 Edisi Februari 2022

Bank Syariah Indonesia uses a lot of debt that is guaranteed by its capital structure in financing the activities and funding of the company's operations. According to Pecking Order Theory, companies will tend to use internal funds first and then use external funds. There are several reasons why a company uses funds in the form of debt, one of which is to avoid the tax burden. If the company's operations are mostly financed by debt, it will not be subject to tax from the company's operations, but if a lot of it is financed by funds from within the company, it will be taxed on the company.

\section{3) Test $\mathrm{t}$}

Partial test is used to determine the effect of each independent variable on the dependent variable. If the significance value is $<0.05$, then there is a simultaneous effect of the independent variable on the dependent variable. Meanwhile, if the significance value is $>0.05$ then there is no simultaneous effect of the independent variable on the dependent variable. (Fadilla, 2017) The results of the t test can be seen in the table below

Tabel 4.7

Hasil Uji t

\begin{tabular}{|c|c|c|c|}
\hline Variabel & $\mathrm{t}$ & signifikansi & kesimpulan \\
\hline DER & 10.264 & .000 & berpengaruh \\
\hline Ln_ROA & -.124 & .902 & Tidak berpengaruh \\
\hline Ln_ROE & -.169 & .867 & Tidak berpengaruh \\
\hline
\end{tabular}

Hipotesis 1

H0 : ROA tidak berpengaruh terhadap DR

H1 : ROA berpengaruh terhadap DR

In the table of t-test results above, it can be seen that the significance value is 0.902 , this value is greater than 0.05 . This means that the ROA variable has no effect on the debt ratio (DR). The results of this test indicate that Hypothesis 1 (first) is rejected. The results of this study reject the results of research conducted by Kesuma and Marentek.

There are several factors that cause companies not to use internal funds, namely: (1) Companies avoid tax burdens, (2) Companies need ROA results to be distributed to shareholders, (3) Merger of 3 Islamic Banks into one Mega Bank is a separate reason why companies do not use returns from assets in financing their companies. 
232 Fadilla \& Lidya Pissatia Asih, Determinant of Capital Structure Policy of Indonesian Sharia Bank...

Hipotesis 2

H0 : ROE tidak berpengaruh terhadap DR

H1 : ROE berpengaruh terhadap DR

In the table of t-test results above, it can be seen that the significance value is 0.867 , this value is greater than 0.05 . This means that the ROE variable has no effect on the debt ratio (DR). The results of this test indicate that Hypothesis 2 (second) is rejected. The results of this study reject the results of research conducted by Kesuma and Marentek.

There are several factors that cause companies not to use internal funds, namely firstly, the company avoids the tax burden. Both companies require the results of the ROE to be distributed to shareholders because ROE is the profit earned from the company's return on capital. Therefore the company does not use ROE in financing its operational activities.

Hipotesis 3

H0 : DER tidak berpengaruh terhadap DR

H1 : DERberpengaruh terhadap DR

In the table of t-test results above, it can be seen that the significance value is 0.00 , this value is smaller than 0.05 . This means that the DER variable has an effect on the debt ratio (DR). The results of this test indicate that Hypothesis 3 (third) is accepted. Companies tend to finance their company's operational activities with debt that can be guaranteed with available capital. The results of this study support the results of research conducted by Kesuma and Yudhiarti. In line with the trade off theory, if internal funds have been exhausted or cannot be used, the company will use external funds, one of which is debt. Debt itself is divided into two, namely short-term debt and long-term debt.

\section{Conclusion}

This study seeks to prove the theory of the Pecking Order which states that companies in financing their operational activities tend to use internal funds and external funds. The results of this study are:

a. ROA (Return on assets) is not proven to have an effect on DR (Debt ratio) 
ISLAMIC BANKING: Jurnal Pemikiran dan Pengembangan Perbankan Syariah, Volume 7 Nomor 2 Edisi Februari $2022 \mid 233$
b. ROE (return on equity) is not proven to have an effect on DR (Debt ratio)
c. DER (Debt to equity ratio) is proven to have an effect on DR (Debt ratio)
d. ROA, ROE. and DER are proven to have an effect on DR 


\section{REFERENCE}

Brigham, Eugene F. dan Houston, J. F. (2001). Manajemen Keuangan (Edisi ke-8). Terjemahan Oleh: Dodo Suharto dan Herman Wibowo. Erlangga.

Cahyo, A., \& Amelia, F. (n.d.). Ipi141421.

Fadilla. (2015). Determinan kebijakan struktur modal serta pengaruhnya terhadap harga saham pada perusahaan yang terdaftar di jakarta islamic index. 1, 21-30.

Fadilla. (2017). Statistik SPSS Untuk Penelitian Keuangan. Noer Fikri.

Firnanti, F. (2011). Faktor-Faktor Yang Mempengaruhi Struktur Modal Perusahaan Manufaktur. 13(2), 119-129.

Ghazali, I. (2017). Aplikasi Analisis Multivariate Dengan Program SPSS. Badan Penerbit Unoversitas Dipogoro.

Hidayat, R. F. (2013). Analisis Faktor-Faktor Yang Mempengaruhi Struktur Modal Pada Perusahaan Manufaktur Terdaftar Di Bursa Efek Indonesia Periode 2007-2011. 2.

Indriastuti, M., Suhendi, C., Islam, U., \& Agung, S. (2021). Financial Risk Analysis For Increasing Financial. 11(2), 203-215.

Kasmir. (2014). Pengantar Manajemen Keuangan. Prenada.

Kesuma, A. (n.d.). Analisis Faktor yang Mempengaruhi Struktur Modal Serta Pengaruhnya Terhadap Harga Saham Perusahaan Real Estate yang Go Public di Bursa Efek Indonesia. 38-45.

Marentek, A. S., Manajemen, J., \& Ekonomi, F. (2015). Analisis Faktor-Faktor Yang Mempengaruhi Struktur Modal Perusahaan Manufaktur Yang Terdaftar Di Bursa Efek Indonesia ( Pada Perusahaan Food And Beverage Periode 2007-2010 ) ( Food And Beverage Company In 2007-2010 ). 15(05), 716726.

Murhadi, W. R. (1984). Determinan Struktur Modal : Studi di Asia Tenggara.

Musthafa. (2015). Manajemen Keuangan. Andyofset.

Neno, H. A. (2018). Analisis Faktor-Faktor yang Mempengaruhi struktur modal PAda Perusahaan Pertambangan yang Terdaftar di Bursa Efek Indonesia Periode 2012-2016.

Nita, N., \& Hairul, A. (2017). Analisis Faktor-faktor yang Mempengaruhi Struktur Modal Perusahaan Sektor Pertambangan. 1(1), 53-65.

Rohadatul. (2015). Faktor-Faktor Yang Mempengariuhi Pertumbuhan Aset Bank Syariah Tahun 2006-2015, 249-265.

Setiawati, R. (2011). Faktor-Faktor Yang Mempengaruhi Struktur Modal ( Survey Pada Perusahaan Sanitaer Di Kota Jambi ). 1(1), 1-17. 
ISLAMIC BANKING: Jurnal Pemikiran dan Pengembangan Perbankan Syariah, Volume 7 Nomor 2 Edisi Februari 2022

Suhendra. (2012). Jurnal skripsi “.

Sunarto, A. (2017). Statsitika Untuk Ekonomi dan BIsnis Islam. Pustaka Pelajar.

Yudhiarti, R., Mohammad, D. H., Mahfud, K., \& Si, M. (2016). Analisis Faktor-Faktor Yang Mempengaruhi Struktur Modal ( Pada Perusahaan Manufaktur Yang Terdaftar Di Bursa Efek Indonesia Periode Tahun 2010-2014 ). 5(1998), 113.

Yusintha, P., \& Suryandari, E. (2010). Analisis Faktor-Faktor Yang Mempengaruhi Struktur Modal ( Studi Empiris pada Perusahaan Manufaktur di Bursa Efek Indonesia ). 11(2), 179-188. 
236 Fadilla \& Lidya Pissatia Asih, Determinant of Capital Structure Policy of Indonesian Sharia Bank............ 